\title{
Evaluasi Kinerja Laporan Keuangan Saham BJTM dan BJBR
}

\author{
Wendra Hartono \\ Universitas Ciputra Surabaya, Citraland CBD Boulevard, Surabaya \\ wendra.hartono@ciputra.ac.id
}

A R T I C L E I N F O

\author{
Article history: \\ Received October 11, 2019 \\ Revised January 14, 2020 \\ Accepted January 14, 2020
}

Key words:

Fundamental, Technical, Government Banking

DOI:

10.33508/jako.v12i1.2169

\begin{abstract}
A B S T R A C T
In the banking world is the front line in the world of leading economy in Indonesia. Several major activities in the banking business sector are related to the number growth of rate interest or credit, inflation rate, bond, digital financial services, term deposit, mutual fund and other instruments. BJBR and BJTM, are categorized as a local government bank which had long been on the floor market since 2010 and 2012. Both of bank shares has been targeted by investors, it is due to their performance are better by the time goes by and the number of dividend per share also constantly high and price per share is still cheap. The aim of this research is more about evaluation of BJBR and BJTM's performances either in fundamental or technical analysis sides also news or fact from these stocks since 2016. The method used in this study is qualitative descriptive, which explore the important incidents occurred. The result of this research shows that BJBR share has better performance and financial report compared to BJTM. Nevertheless, it is still needed to be considered that price per share of BJTM is much cheaper than BJBR.
\end{abstract}

\begin{abstract}
A B S T R A K
Dunia perbankan merupakan lini terdepan dalam perekonomian di Indonesia. Beberapa kegiatan utama dalam bisnis perbankan itu berhubungan dengan angka pertumbuhan bunga pinjaman atau kredit, tingkat inflasi, penerbitan obligasi, layanan digital keuangan, deposito, reksadana dan lain sebagainya. BJBR dan BJTM, merupakan bank pemerintah daerah yang sudah lama berada dilantai bursa sejak tahun 2010 dan 2012. Kedua saham bank daerah ini menjadi buruan dari para investor, hal ini disebabkan karena kinerja perusahaan yang semakin baik, jumlah dividen per tahun nya yang tinggi serta harga saham per lembarnya juga masih cenderung murah. Tujuan penelitian ini adalah untuk mengkaji lebih dalam tentang evaluasi kinerja BJTM dan BJBR baik dari sisi fundamental perusahaan, analisa teknikal dan kebijakan atau fakta berita perusahaan sejak tahun 2016. Metode yang dipakai dalam penelitian ini adalah uji kualitatif deskriptif, dengan mengeksplor kejadian-kejadian penting yang terjadi. Hasil penelitian ini adalah BJBR memiliki performa kinerja dan laporan keuangan yang lebih baik dibandingkan dengan BJTM, namun harga saham per lembar BJTM jauh lebih murah dibandingkan dengan BJBR.
\end{abstract}

\section{PENDAHULUAN}

Kegiatan utama dari perusahaan perbankan adalah menghimpun dana dari masyarakat dalam bentuk simpanan dan menyalurkannya kembali kepada masyarakat dalam berbagai bentuk investasi ataupun pemberian pinjaman kredit yang berguna untuk meningkatkan taraf hidup rakyat (Mudawamah, Wijono, dan Hidayat, 2018). Dunia perbank-an sangatlah dibutuhkan kepercayaan dari masyarakat untuk menanamkan modalnya atau menginvestasikan uangnya ke bank tersebut. Maka dari itu setiap bank harus bersaing secara sehat untuk memperoleh kepercayaan itu, dengan memberikan kinerja yang semakin baik kepada masyarakat. Untuk melakukan perbaikan kinerja dapat dilakukan dengan cara menjaga dan meningkatkan kualitas produk yang terbaik, kualitas layanan, dan efisiensi biaya (Mudawamah, Wijono, dan Hidayat, 2018).

Terdapat dua cara untuk melakukan evaluasi kinerja perusahaan yaitu analisa fundamental dan teknikal dimana analisa fundamental melibatkan analisis kinerja operasional perusahaan untuk menilai perkembangan prospek ekonomi di kemudian hari (Fabozzi, 2009). Menurut Munawir (2010) Analisis laporan keuangan ini bertujuan untuk memberikan informasi kondisi keuangan suatu perusahaan, yang terdiri dari informasi jumlah dan 
jenis aktiva, kewajiban (hutang) serta kepemilikan modal, dimana semua dituliskan dalam neraca.Selain itu Munawir (2010) menambahkan penjelasannya bahwa fungsi dari laporan keuangan juga memberikan gambaran tentang hasil usaha perusahaan dalam suatu periode tertentu yang dituangkan dalam laporan laba rugi.Laporan keuangan juga dapat tertuang dalam laporan arus kas, dimana arus kas memiliki peran penting sebagai likuiditas dalam kegiatan keluar masuknya kas.

Akan tetapi, pengukuran kinerja laporan perusahaan saja tidaklah cukup mewakili pergerakan harga saham, sehingga dibutuhkan pengukuran yang bersifat non-financial seperti analisa teknikal dan kondisi global yang dapat digunakan untuk mengembangkan sebuah pengukuran standar yang dapat menjelaskan strategi bisnis perusahaanyang akan berdampak pada pergerakan harga saham (Kaplan dan Norton, 1992). Selain itu, tren dan masalah ekonomi global yang terjadi, seperti kondisi politik, perang tarif antara Amerika dan China, kenaikan atau penurunan suku bunga bank, isu lingkungan sosial, masih menjadi bahan perdebatan oleh beberapa analis dalam mengukur pergerakan harga saham secara teknikal (Dropsy, 1996).

Tujuan penelitian ini adalah untuk mengkaji kinerja dua perusahaan per-bankan BUMN, BJBR dan BJTM selama 3.5 tahun terakhir dari sisi analisis fundamental yang mengacu pada rasio analisis sederhana seperti ROA, ROE, Book Value, EPS, DER, Total Asset, Total Equity dan NPM. Rasio ini dipilih peneliti karena rasio ini dirasa sudah menunjukkan performa atau kondisi kesehatan perusahaan yang ada untuk dievaluasi. Selain itu, peneliti juga meninjau dari sisi analisis teknikal akan membahas secara sederhana tentang indikator Moving Average, serta peneliti menyajikan data fakta tentang kebijakan yang diambil perusahaan yang akan berdampak pada pergerakan harga saham. Pergerakan kedua saham ini cukup menarik di lantai bursa, selain karena keduanya merupakan perusahaan perbankan milik pemerintah daerah (BUMN), kinerja perusahaan yang semakin baik setiap tahunya, dan jumlah dividen yang dibagikan juga besar kurang lebih sebesar Rp 89/lembar saham BJBR dan Rp45/lembar saham BJTM. Akan tetapi dengan kinerja perusahaan yang semakin baik, nilai dividen yang dibagikan tidak berubah, sehingga menyebabkan para investor untuk meninjau ulang apakah kedua saham ini masih layak di investasikan atau tidak.Jika masih layak, diantara kedua saham ini, manakah yang lebih layak untuk di beli. Hasil penelitian ini diharapkan dapat memberikan masukan atau sebagai referensi bagi para investor sebelum memilih saham perusahaan yang akan diinvestasikan.

Permasalahan dalam penelitian ini adalah bagaimana kinerja bank Jabar dan Banten (BJBR) dan Bank Jatim (BJTM) selama 3,5 tahun terakhir sejak 2016.

Kebaharuan dalam penelitian ini adalah peneliti melakukan studi perbandingan data hasil yang telah di peroleh antara BJTM dan BJBR, dari tiga sudut pandang analisis yang berbeda.Hasil penelitian dapat memberikan kontribusi tambahan bagi para praktisi pasar modal denganmenggunakan informasi analisis rasio, teknikal dan fakta yang telah tersaji dalam penelitian ini.

\section{Batasan Penelitian}

Pada penelitian ini akan diberikan batasan dalam analisis fundamental hanya terdapat dalam rasio-rasio keuangan sederhana seperti sebagian dari rasio profitabilitas (return on asset dan return on equity), rasio solvabilitas (debt equity ratio) dan rasio ukuran pasar (earning per share).

\section{KAJIAN LITERATUR}

Alat analisis dalam penelitian ini ada tiga, diantaranya fundamental analisis, teknikal analisis dan berita yang akan berdampak pada keputusan perusahaan dalam mengambil keputusan yang diambil. Ketiga analisis ini diharapkan dapat memberikan gambaran dan pertimbangan sebelum membeli saham.

\section{Analisis Fundamental}

Dalam menilai kinerja perusahaan dibutuhkan suatu analisis pada rasio-rasio keuangan setiap tahunnya untuk mengetahui apakah perusahaan tersebut berkembang atau tidak.Analisis laporan keuangan atau disebut dengan analisis fundamental adalah salah satu alat untuk mengukur rasiorasio keuangan suatu perusahaan dengan menggunakan perhitungan artitmatika sederhana yang dapat di interpretasikan dan dibandingkan dengan perhitungan rasio tahun-tahun sebelumnya (Hery, 2017).

Tujuan utama dari Analisis Fundamental atau laporan keuangan (Financial Statement Analysis) adalah (1) Sebagai sebuah alat barometer untuk melakukan peramalan atau memproyeksikan posisi keuangan dimasa yang akan datang; (2) Meninjau ulang kondisi perusahaan, permasalahan yang muncul dalam manajemen, operasional maupun, keuangan yang terjadi saat ini dan (3) sebagai Alat ukur untuk melakukan efisiensi di semua divisi perusahaan (Erica, 2017). 
Dalam penelitian ini akan di paparkan beberapa jenis rasio keuangan yang meliputi :

1. Rasio profitabilitas, yang meliputi perhitungan return on asset (ROA) dan return on equity (ROE)

2. Rasio solvabilitas, misalnya debt equity ratio (DER)

3. Rasio ukuran pasar, meliputi rasio laba per lembar saham / earning per share (EPS)

Kang dan Petzke (2009) menjelaskan bahwa rasio profitabilitas merupakan rasio yang menghitung perkiraan keberhasilan profit atau operasional suatu entitas dalam periode waktu tertentu. Return on asset atau ROA mengukur laju pengembalian setiap satu uang yang di investasikan dalam suatu asset. Return on equity (ROE) adalah suatu rasio yang mengukur tingkat keuntungan dari sudut pandang pemegang saham biasa atau ordinary shareholders, yaitu jumlah setiap uang dari keuntungan terhadap setiap uang yang di investasikan oleh investor.

Menurut Heri (2017) rasio solvabilitas, adalah suatu rasio yang menunjukkan kemampuan perusahaan dalam membayar seluruh kewajibannya.Hal ini diperuntukkan dalam menganalisis kredit atau resiko keuangan.Debt to Equity Ratio (DER) merupakan rasio yang mengukur nilai banding antara total utang dengan ekuitas.

Menurut Heri (2017) rasio ukuran pasar merupakan sebuah rasio yang mengukur nilai perkiraan intrinsik suatu perusahaan.Dalam penelitian ini, peneliti mengukur EPS, bila angka EPS tinggi, hal ini menggambarkan keberhasilan manajemen perusahaan dalam memberikan keuntungan bagi para investor saham biasa.Rasio ini menjelaskan hubungan antara laba bersih perusahaan dengan kepemilikan pemegang saham.

Menurut Tryfino (2009) mengatakan book value adalah nilai atau harga buku per lembar saham, yang mengindikasikan jumlah aset atau ekuitas yang dimiliki oleh perusahaan tersebut.

Net Profit Margin menurut Animah, dkk.(2009) dalam jurnalnya yang berjudul Pengaruh Profit Margin, Investment Turnover, Equity Multiplier terhadap Return on Equit, adalah nilai rasio antara laba bersih dengan penjualan, dimana nilai penjualan sudah dikurangi dengan seluruh biaya termasuk pajak.Semakin tinggi nilai NPM maka semakin baik kinerja suatu perusahaan, karena hal ini menunjukkan kemampuan perusahaan memperoleh keuntungan dari penjualan.

Nilai Total Asset menunjukkan nilai kekayaan atau harta yang dimiliki oleh suatu perus-
ahaan.Sedangkan nilai Total Equity menunjukkan nilai kepemilikan oleh suatu perusahaan. Apabila kedua nilai ini semakin tinggi nilainya dari periode ke periode selanjutnya maka hal ini menunjukkan kekayaan aset dan kepemilikan meningkat, dengan kata lain perusahaan terus bertumbuh.

\section{Analisis Teknikal}

Technical analysis adalah suatu analisa yang menggunakan data statistik dari pergerakan harga saham terdahulu yang digunakan untuk melakukan evaluasi saham, komoditas dan lain sebagainya guna untuk memprediksi kemungkinan pergerakan saham kedepannya (Ong, 2008).

Pada penelitian ini akan digunakan beberapa metode analisis teknikal sederhana yang menggunakan bagan candle chart. Adapun dua macam indikator yang digunakan yaitu Lagging Indicators dan Leading Indicators. Lagging indicators adalah suatu indikasi yang digunakan untuk mendeteksi trend, sebagai contoh dari indikator ini adalah Moving Average (MA),sedangkan Leading Indicators digunakan untuk mengetahui momentum apakah suatu saham yang diperdagangkan dalam pasar sedang dalam keadaan oversold atau overbought sebagai contohnya adalah Relative Strength Index (RSI).

\section{Fakta dan Kebijakan Perusahaan}

Setiap aksi atau keputusan diambil perusahaan akan membawa dampak kedepannya baik berdampak positif atau negative. Semua dampak tersebut akan mempengaruhi pergerakan stokastik harga saham pada lantai bursa. Pada penelitian ini, berita dan kebijakan yang dipilih dan diambil sesuai dengan publikasi yang diperoleh dari koran Kontan elektronik sejak 2017.

\section{METODE PENELITIAN}

Populasi dalam penelitian ini adalah Bank yang sudah tercatat dalam lantai bursa.Sampelnya disini yang dipilih adalah Bank Pemerintah Daerah yang sudah tercatat dalam dunia saham, yaitu Bank Jabar dan Banten (BJBR) dan Bank Jatim (BJTM).

Peneliti menggunakan sumber data sekunder, dimana data yang dipilih diperoleh dari berbagai macam buku, jurnal ataupun referensi-referensi lainnya, seperti berita dari koranonline, textbook akuntansi dan laporan keuangan perusahaan. Kebijakan peraturan pemerintah Indonesia akan berdampak pada tindakan atau wewenang perusahaan dalam mengambil keputusan dan menjalankan kegiatan operasionalnya sehari-hari dalam kurun waktu 3,5 tahun terakhir. Data yang dik- 
umpulkan akan disimpan sebagai dokumen untuk dijadikan sebagai data pendukung dalam mengevaluasi kinerja perusahaan.

Pada penelitian ini, peneliti menggunakan teknik penelitian deskriptif kualitatif, yang menurut Komariah dan Satori (2011) didefinisikan sebagai metode yang dilakukan oleh peneliti yang ingin mengeksplor beberapa fenomena yang tidak dapat dikuantifikasikan dan bersifat deskriptif seperti suatu proses langkah kerja, formula suatu resep, definisi tentang konsep yang beragam, ciriciri suatu barang dan jasa, gambar, model atau gaya, tata cara suatu budaya dan lain-lain. Periode yang digunakan penelitian ini adalah sejak 2016.

Selain itu menurut Sukmadinata (2011), menjelaskan bahwa sebuah penelitian deskriptif kualitatif ditujukan untuk menggambarkan dan mendsekripsikan tentang fenomena-fenomena yang terjadi, baik bersifat alamiah ataupun buatan, yang lebih memperhatikan karakteristik, kualitas, serta keterkaitan antar kegiatan. Selain itu, dalam penelitian deskriptif, peneliti tidak memberikan perlakuan, manipulasi atau pengubahan data-data yang diteliti, melainkan mendeskripsikan suatu kondisi yang apa adanya.

Objek penelitian ini adalah bank Badan Usaha Milik Negara (BUMN) yaitu BJBR dan BJTM. Pemilihan dua bank BUMN sebagai obyek dari penelitian karena perusahaan sebagai bagian dari program restrukturisasi perbankan daerah yang di laksanakan oleh pemerintah Indonesia, dimana bergerak dibidang jasa dengan memberikan penawaran jasa pelayanan kredit atau pinjaman bagi khalayak luas. Setiap bank tersebut memiliki peran penting yang tak bisa terpisahkan dalam pembangunan dan perekonomian nasional.

\section{HASIL DAN PEMBAHASAN}

\section{Analisis Fundamental}

Berdasarkan data pada tabel 1, perbandingan nilai ROA BJTM year on year (yoy) dari tahun 2016 sampai 2018 adalah $-5.86 \%$ dan $-10.67 \%$. Nilai yoy mengalami penurunan yang cukup signifikan dibandingkan dengan nilai ROA BJBR year on year (yoy) dari tahun 2016 sampai 2018. Besarnya nilai tersebut adalah $-7.08 \%$ dan $+22.86 \%$. Hal ini menunjukkan bahwa nilai pengembalian atas aset BJBR mengalami kenaikan yang signifikan bila dibandingkan dengan BJTM. Dari 31 Desember 2018 sampai kuartal pertama 2019, nilai ROA BJBR mengalami kenaikan menjadi $1.43 \%$, sedangkan nilai ROA BJTM meningkat cukup signifikan menjadi $2.73 \%$.

Perbandingan nilai ROE BJBR year on year (yoy) dari tahun 2016 sampai 2018 adalah $+0.42 \%$ dan $+14.45 \%$. Nilai yoy mengalami kenaikan yang cukup signifikan dibandingkan dengan nilai ROE BJTM year on year (yoy) dari tahun 2016 ke tahun 2017, dan dari tahun 2017 ke 2018. Besarnya nilai tersebut adalah $+4.00 \%$ dan $+0.34 \%$, dimana nilai positif masih dibukukan oleh saham BJTM ini meskipun kenaikan nilai ROEnya kecil.Hal ini menunjukkan bahwa nilai pengembalian atas ekuitas dalam menciptakan laba bersih BJBR mengalami kenaikan yang signifikan bila dibandingkan dengan BJTM. Dari 31 Desember 2018 sampai kuartal pertama 2019, nilai ROE BJBR mengalami kenaikan menjadi $14.4 \%$, sedangkan nilai ROE BJTM meningkat cukup signifikan menjadi $2.73 \%$.

\section{Tabel 1. Perbandingan Laporan Keuangan BJBR} dan BJTM

\begin{tabular}{|c|c|c|c|c|c|c|c|c|}
\hline & \multicolumn{4}{|c|}{ BJBR } & \multicolumn{4}{|c|}{ BJTM } \\
\hline & $\begin{array}{c}31 \\
\text { Maret }\end{array}$ & 2018 & 2017 & 2016 & 31 Maret & 2018 & 2017 & 2016 \\
\hline & 2019 & & & & 2019 & & & \\
\hline ROA & 1.43 & 1.29 & 1.05 & 1.13 & 2.73 & 2.01 & 2.25 & 2.39 \\
\hline ROE & 14.4 & 13.78 & 12.04 & 11.99 & 20.01 & 14.88 & 14.83 & 14.26 \\
\hline $\begin{array}{l}\text { Book } \\
\text { Value }\end{array}$ & $\begin{array}{c}1,184 . \\
71\end{array}$ & $\begin{array}{c}1,142 . \\
07\end{array}$ & $\begin{array}{c}1,037 . \\
09\end{array}$ & 993.35 & 504.01 & 565.62 & 522.94 & 483.29 \\
\hline EPS & 170.56 & 157.36 & 125 & 119.06 & 100.85 & 84.14 & 77.57 & 68.93 \\
\hline DER & 8.67 & 9.62 & 9.82 & 9.26 & 6.34 & 6.4 & 5.59 & 4.97 \\
\hline $\begin{array}{l}\text { Total } \\
\text { Asset }\end{array}$ & $\underset{\mathrm{T}}{117.76}$ & $\begin{array}{c}120.19 \\
\mathrm{~T}\end{array}$ & $\underset{\mathrm{T}}{114.98}$ & $\stackrel{102.32}{\mathrm{~T}}$ & $55.31 \mathrm{~T}$ & $62.69 \mathrm{~T}$ & $\stackrel{51.52}{\mathrm{~T}}$ & $43.03 \mathrm{~T}$ \\
\hline $\begin{array}{l}\text { Total } \\
\text { Equity }\end{array}$ & $\begin{array}{c}11.66 \\
\mathrm{~T}\end{array}$ & $\begin{array}{c}11.24 \\
\mathrm{~T}\end{array}$ & $\begin{array}{c}10.06 \\
\mathrm{~T}\end{array}$ & $9.63 \mathrm{~T}$ & $7.53 \mathrm{~T}$ & $8.47 \mathrm{~T}$ & $7.82 \mathrm{~T}$ & $7.21 \mathrm{~T}$ \\
\hline $\begin{array}{l}\text { Net Profit } \\
\text { Margin }\end{array}$ & 13.11 & 12.05 & 9.8 & 10.09 & 29.26 & 22.45 & 22.04 & 19.53 \\
\hline
\end{tabular}

Sumber: RTI Business

Dari sisi book value, harga saham BJBR dan BJTM cenderung mengalami kenaikan sejak tahun 2016 sampai 2018.Hal ini menunjukkan bahwa harga wajar di lantai bursa untuk saham BJBR dan BJTM semakin meningkat setiap tahunnya.Selain itu, nilai buku yang semakin meningkat dapat menunjukkan performa perusahaan yang juga semakin baik.

Apabila ditinjau dari sisi Earning Per Share (EPS), BJBR mengalami kenaikan yoy dari $+25.89 \%$ sejak tahun 2017 ke 2018, sedangkan sejak tahun 2016 ke 2017 mengalami kenaikan yoy sebesar $+4.99 \%$. Bila dibandingkan dengan BJTM, nilai EPS 
mengalami kenaikan yoy dari tahun 2017 ke 2018 dan 2016 ke 2017 adalah sebesar $+8.47 \%$ dan $+12.53 \%$. Dalam hal ini, apabila dirata-rata selama 2 tahun nilai persentase EPS BJBR jauh mengalami kenaikan dibandingkan dengan BJTM. Selama 3 bulan sejak akhir pembukuan 31 Desember2018, nilai EPS dari BJBR dan BJTM mengalami pertumbuhan yang baik, yaitu +13.2 dan +16.71. Nilai EPS yang meningkat menunjukkan kinerja perusahaan yang baik pula, dan akan memberikan dampak secara tidak langsung terhadap pergerakan harga saham. Hal ini senada dengan hasil penelitian yang diungkapkan oleh Mulia dan Nurdhiana (2012) yang menyatakan bahwa nilai EPS berpengaruh signifikan dengan harga saham yang beredar.

Ditinjau dari sisi debt equity ratio (DER) BJTM mengalami fluktuasi yoy mengalami kenaikan $+14.49 \%$ dari tahun 2017 ke 2018 dan $+12.47 \%$ dari tahun 2016 ke 2017. Sedangkan untuk saham BJBR nilai DER nya juga berfluktuasi yoy nya dari tahun 2017 ke 2018 adalah $-5.70 \%$ dan dari 2016 ke 2017 adalah $+2.08 \%$. Nilai DER BJBR pada 31 Maret 2019 adalah 8.67 menunjukkan bahwa pada tahun berjalan 2019 rasio utang sedikit lebih baik dibandingkan dengan tahun-tahun sebelumnya yang memiliki nilai 9.62, 9.82 dan 9.26. Sedangkan nilai DER BJTM pada 31 Maret 2019 adalah 6.34 menunjukkan bahwa pada tahun berjalan 2019 rasio utang sedikit buruk dibandingkan dengan tahun-tahun sebelumnya yang memiliki nilai 6.4, 5.59 dan 4.97.

Pergerakan nilai total aset dan equity untuk masing-masing saham BJBR dan BJTM sama-sama mengalami pertumbuhan yang baik. Nilai total aset yoy 2016 ke 2017 untuk BJBR dan BJTM adalah $+12.37 \%$ dan $+19.72 \%$, sedangkan nilai total equity yoy 2016 ke 2017 untuk BJBR dan BJTM adalah $+4.49 \%$ dan $+8.41 \%$. Pada tahun 2017 ke 2018, nilai total aset BJBR dan BJTM adalah $+4.53 \%$ dan $+21.68 \%$, sedangkan untuk nilai total ekuitas BJBR dan BJTM adalah $+11.65 \%$ dan $+8.39 \%$. Nilai total aset BJTM yoy 2018 memang cukup sangat signifikan bila dibandingkan dengan BJBR. Namun nilai total ekuitas BJBR jauh lebih besar daripada BJTM. Hal ini berarti bahwa pada yoy 2017 dan 2018, BJBR memiliki nilai kewajiban yang lebih kecil dibandingkan dengan tahun sebelumnya sehingga nilai ekuitas dapat mengalami pertumbuhan besar, sedangkan BJTM masih memiliki kewajiban yang lebih besar dari tahun sebelumnya.

Nilai net profit margin (NPM) pada perusahaan BJBR dan BJTM mengalami pertumbuhan sejak tahun 2016 sampai ke triwulan pertama 2019.Berdasarkan data tabel diatas, dapat dijelaskan jika nilai NPM BJTM selalu mengalami kenai- kan setiap tahunnya, dan nilainya jauh lebih besar dibandingkan dengan nilai BJBR. Nilai NPM BJBR ditahun 2017 mengalami penurunan dalam memberikan pelayanan kredit kepada perusahaan yang membutuhkan dana pinjaman.

\section{Analisis Teknikal}

Berdasarkan Grafik Chart Nexus di gambar 1, sejak tahun 2016 garis Moving Average 20, 50 dan 100 menunjukkan peningkatan atau dalam kondisi uptrend.Hal ini dibuktikan dengan garis MA 20 tidak memotong MA 50 dan 100. Sedangkan di sepanjang tahun 2017, pada bulan Januari - Mei terjadi penurunan garis MA 20, dimana garis MA 20 berada dibawah garis MA 50 dan 100 . Hal ini menunjukkan bahwa harga saham BJBR sedang mengalami penurunan atau bearish. Sekitar akhir bulan mei 2017, ada indikasi bullish sementara yang ditunjukkan dengan munculnya candle stick yang meningkat selama 2 hari transaksi perdagangan. Namun keadaan bullish tersebut hanya bersifat sementara sebagai akibat koreksi penurunan yang cukup dalam.Dalam bulan Juni - Agustus 2017 menunjukkan posisi harga saham yang sideways. Pada Bulan Agustus 2017, pergerakan harga saham bullish yang cukup tinggi sebagai akibat release laporan keuangan kuartal kedua yang disinyalir memiliki performa positif dibandingkan year on year 2016. Di akhir kuartal IV, garis MA 20 menunjukkan penurunan kembali yang memotong MA 50 dan 100, hal ini berarti bahwa kondisi harga saham cenderung mengalami penurunan.

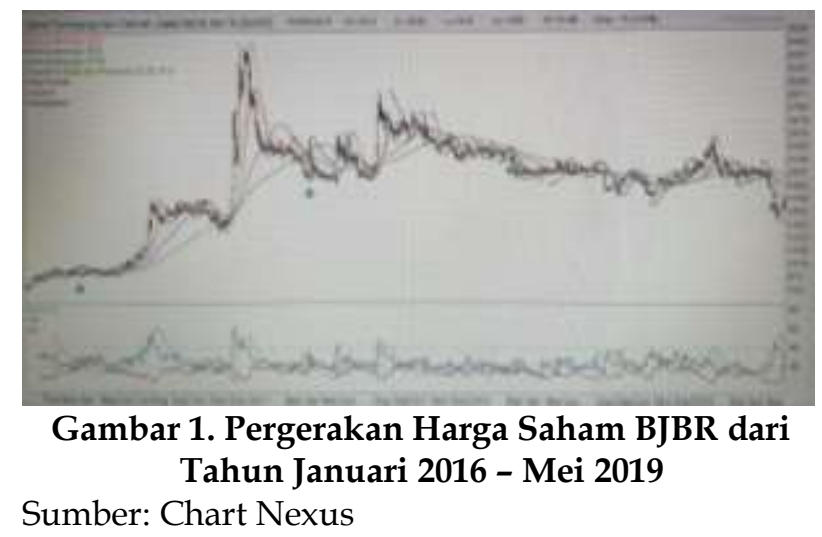

Di tahun 2018, pada kuartal 1, pergerakan harga saham BJBR, masih cenderung dalam kondisi bearish.Candle stick belum mampu menunjukkan kemampuannya untuk menembus garis MA 20, 50 dan 100. Belum ada sentiment pasar yang positif yang mampu mendorong bergeraknya harga saham BJBR ini.Terlebih pada bulan Maret, Perusahaan membagikan deviden, sehingga pasca devi- 
den pergerakan harga saham terkoreksi hampir $11 \%$.Pada kuartal 2, harga saham berada pada posisi sideways, tidak menunjukkan ada tanda-tanda perubahan.Pada kuartal 3, terjadi penurunan harga saham akibat diluncurkannnya laporan keuangan pertengahan tahun, dimana laporan keuangan tersebut memiliki performa yang lebih buruk bila dibandingkan dengan yoy 2016.Harga saham mengalami gejolak naik dan turun sampai dilevel terendah di harga 1710. Pada saat harga bergejolak membentuk pola head and shoulder, yang berdampak pada kuartal ke 42018 mengalami kenaikan harga saham.

Di tahun 2019, diawal bulan Januari sampai Februari mengalami bullish yang bersifat sementara. Hal ini mungkin dapat disebabkan karena January effect dan pola analisis teknis head and shoulder dari harga saham BJBR itu sendiri. Pada bulan Februari-Mei, harga saham dalam posisi sideways dimana tidak menunjukkan adanya gejolak pergerakan harga.Pada bulan Mei, adanya aksi korporasi yang dilakukan dengan pembagian deviden dan munculnya kinerja laporan keuangan yang buruk dibandingkan yoy 2018 menyebabkan harga saham anjlok hampir $25 \%$.

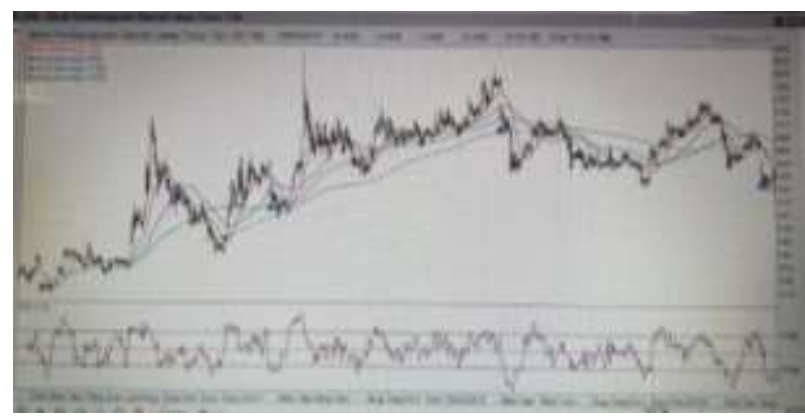

Gambar 2. Pergerakan Harga Saham BJTM dari Tahun Januari 2016 - Mei 2019

Sumber : Chart Nexus

Berdasarkan grafik di gambar 2, pada tahun 2016 di kuartal 1, saham BJTM mengalami pergerakan bullish dan bearish yang seirama. Hal ini ditunjukkan dengan garis MA 20 berpotongan dengan MA 100 dan 200.Pada kuartal II masih mengalami posisi sideways.Tidak terbentuk pola parabolic dan reversal.Pada awal bulan Juli, pergerakan stokastik harga saham BJTM mengalami gejolak.Harga saham BJTM meningkat cukup tinggi sebesar $70 \%$ selama satu bulan.Hal ini disebabkan karena terpublikasikannya laporan keuangan BJTM yang baik dibandingkan year on year 2015.Namun kenaikan tersebut terkoreksi sampai akhir bulan November.
Pada bulan Desember sampai Februari 2017 terjadi gejolak kenaikan harga yang cukup signifikan yang ditandai dari kenaikan candle stock yang melebihi garis Moving Average 20. Akan tetapi di bulan Februari terjadi penurunan, dikarenakan adanya pembagian dividen.Reaksi pasar dan kondisi perusahaan yang bagus mendorong saham BJTM bergerak positif secara teknikal hal ini dibuktikkan dengan melonjaknya harga pasar dari bulan Maret 2017 sampai Maret 2018.Namun dipertengahan tahun 2017, harga saham BJTM mengalami koreksi harga setelah mengalami kenaikan yang cukup tinggi.Namun pada bulan Juli-Agustus mengalami perubahan pembalikan arah, dikarenakan kinerja perusahaan yang baik, yang didukung dengan laporan keuangan kuartal 2 yang positif.

Di kuartal II dan III 2018, saham BJTM mengalami pergerakan statis atau dalam posisi sideways. Hal ini ditandai dengan garis support dan resistance bergerak sejajar dan seirama dengan arah grafik. Selain itu Garis Moving Average 20,50,100 dan 200 tidak menunjukkan perbedaan yang signifikan.

Dikuartal IV 2018, menunjukkan pengulangan trend yang terjadi seperti pada tahun-tahun sebelumnya. Hal ini didukung aksi pengumpulan saham BJTM secara massive untuk memperoleh dividen pada bulan Maret 2019, dengan DPR sebesar kurang lebih 6\% per tahun.Pada Kuartal II 2019, setelah pembagian dividen interim, saham BJTM menunjukkan adanya pelemahan atau bearish trend dan cenderung dalam kondisi sideways. 
Tabel 2.Berita Yang Berdampak Pada Harga Saham BJTM

\begin{tabular}{|c|c|c|c|c|}
\hline No. & Tanggal & Fakta atau Kebijakan & $\begin{array}{c}\text { Dampak terhadap } \\
\text { Perusahaan }\end{array}$ & $\begin{array}{c}\text { Harga Penutupan saham } \\
\text { dari hari sebelumnya. }\end{array}$ \\
\hline 1. & 22 Januari 2016 & $\begin{array}{l}\text { Bank Jatim bekerjasama dengan Jam Krindo (Perus- } \\
\text { ahaan Umum Jaminan Kredit Indonesia) tentang Pen- } \\
\text { jaminan kredit. Pinjaman kredit meliputi penjaminan } \\
\text { kredit multiguna, mikro, kontra bank garansi, kon- } \\
\text { struksi pola keppres dan pola standbye loan. }\end{array}$ & $\begin{array}{l}\text { Dengan adanya kerjasama ini, } \\
\text { diharapkan kinerja volume } \\
\text { penjaminan kedua belah pihak } \\
\text { meningkat. }\end{array}$ & $\begin{array}{l}\text { Harga saham ditutup } \\
\text { melemah dari harga } \\
\text { sebelumnya. }\end{array}$ \\
\hline 2. & 21 Juli 2016 & $\begin{array}{l}\text { PT. Bank Pembangunan Daerah Jawa Timur Tbk. akan } \\
\text { melakukan ekspansi pada semester II } 2016 \text { dengan } \\
\text { membuka kantor cabang di Batam, Kepulauan Riau. }\end{array}$ & $\begin{array}{l}\text { BJTM memperluas wilayah } \\
\text { pembukaan kantor cabang di } \\
\text { berbagai wilayah di Indonesia. }\end{array}$ & $\begin{array}{l}\text { Harga saham ditutup } \\
\text { melemah dari harga } \\
\text { sebelumnya. }\end{array}$ \\
\hline 3. & $\begin{array}{ll}04 & \text { September } \\
2016 & \end{array}$ & $\begin{array}{l}\text { PT. Bank Pembangunan Daerah Jawa Timur Tbk. } \\
\text { terkena dampak atas kebijakan pemerintah dalam } \\
\text { penundaan penyaluran Dana Alokasi Umum (DAU). }\end{array}$ & $\begin{array}{l}\text { Dengan penundaan DAU maka } \\
\text { dana pemda yang ada di DPK } \\
\text { bank berkurang. Untuk menga- } \\
\text { tasi hal tersebut, Bank Jatim } \\
\text { akan memperbanyak CASA } \\
\text { dengan meluncurkan laku } \\
\text { pandai dan tabungan prioritas. }\end{array}$ & $\begin{array}{l}\text { Harga saham ditutup } \\
\text { melemah dari harga } \\
\text { sebelumnya. }\end{array}$ \\
\hline 4. & $\begin{array}{l}25 \text { Desember } \\
2016\end{array}$ & $\begin{array}{l}\text { BJTM akan buy back saham dipasar regular. Dana } \\
\text { berasal dari saldo laba per September } 2016 \text { sebesar } \\
\text { Rp.836,57 miliar. }\end{array}$ & $\begin{array}{l}\text { BJTM mengalokasikan dana } \\
\text { sebanyak-banyaknya Rp 1,2 } \\
\text { Miliar yang akan dilakukan } \\
\text { secara bertahap sejak } 1 \text { Februari } \\
2017 \text { hingga 1 Juni } 2017\end{array}$ & $\begin{array}{l}\text { Tidak terjadi transaksi } \\
\text { pada hari libur bursa. } \\
\text { Namun pada tanggak } 26 \\
\text { desember 2016, harga } \\
\text { saham perdagangan di } \\
\text { bursa ditutup melemah. }\end{array}$ \\
\hline 5. & 02 Februari 2017 & $\begin{array}{l}\text { Bank Jatim akan membagikan dividen tahun buku } 2016 \\
\text { sebesar Rp. } 652,2 \text { miliar atau setara dengan Rp. } 43 \text { per } \\
\text { saham. }\end{array}$ & $\begin{array}{l}\text { Pembagian dividen telah disetu- } \\
\text { jui dalam RUPS tahunan } 2016 \text { di } \\
\text { Surabaya pada 31 Januari } 2017 .\end{array}$ & $\begin{array}{l}\text { Harga saham ditutup } \\
\text { menguat dari harga sebe- } \\
\text { lumnya. }\end{array}$ \\
\hline 6. & 20 April 2017 & $\begin{array}{l}\text { Laba bersih BJTM naik secara tahunan year on year } \\
\text { (yoy), dari segemen kredit program kerja, yang berna- } \\
\text { ma yaitu Pundi Kencana dan Laguna, tumbuh masing- } \\
\text { masing sebesar } 10,13 \% \text { dan } 106,5 \% \text {. Selain itu Kredit } \\
\text { mikro perseroan SiUmi (Siklus Mikro kecil) melonjak } \\
\text { 902,15\% yoy. }\end{array}$ & $\begin{array}{l}\text { Laba BJTM pada kuartal I } 2017 \\
\text { mengalami kenaikan sebesar } \\
8,68 \% \text { atau Rp. } 340 \text { miliar. }\end{array}$ & $\begin{array}{l}\text { Harga saham ditutup } \\
\text { melemah dari harga } \\
\text { sebelumnya. }\end{array}$ \\
\hline 7. & 25 Oktober 2017 & $\begin{array}{l}\text { BJTM mencatat kenaikan realisasi laba untuk } 9 \text { bulan } \\
\text { pertama tahun } 2017 \text {, sebesar Rp. } 1,01 \mathrm{~T} \text {. Kenaikan laba } \\
\text { ini naik sebesar } 21,18 \% \text { yoy. Kenaikan terbesar di } \\
\text { dorong oleh peningkatan kredit pada pembiayaan } \\
\text { sector consumer sebesar } 8,64 \% \text { yoy. Namun dua seg- } \\
\text { men kredit lainnya yaitu Usaha Kecil dan Menengah } \\
\text { (UKM) dan komersia mengalami penurunan sebesar } \\
2,1 \% \text { dan } 6,9 \% \text { yoy. }\end{array}$ & $\begin{array}{l}\text { Laba Bank Jatim Kuartal III } \\
\text { mencapai Rp } 1 \mathrm{~T} \text {. }\end{array}$ & $\begin{array}{l}\text { Harga saham ditutup } \\
\text { melemah dari harga } \\
\text { sebelumnya. }\end{array}$ \\
\hline 8. & 26 Maret 2018 & $\begin{array}{l}\text { BJTM menggunakan dana sebesar Rp. } 1 \text { Miliar untuk } \\
\text { membeli saham kembali pada periode } 7 \text { Desember } 2017 \\
\text { - } 1 \text { April 2018. Jumlah saham hasil buyback akan ma- } \\
\text { suk sebagai treasury stock perseroan. }\end{array}$ & $\begin{array}{l}\text { Bank Jatim melakukan buyback } \\
1,39 \text { juta lembar saham. } \\
\text { Tujuannya adalah untuk pro- } \\
\text { gram jangka Panjang insentif } \\
\text { atau (LTI). }\end{array}$ & $\begin{array}{l}\text { Harga saham tidak men- } \\
\text { galami perubahan atau } \\
\text { stagnan. }\end{array}$ \\
\hline 9. & 24 Juli 2018 & $\begin{array}{l}\text { Kenaikan suku bunga pertumbuhan dana pihak ketiga } \\
\text { atau DPK di semester I } 2018 \text { lebih besar daripada ke- } \\
\text { naikan kredit. Alhasil, net interest margin BJTM akan } \\
\text { susut menjadi } 6,45 \% \text { dari } 6,68 \% \text {. }\end{array}$ & $\begin{array}{l}\text { Beban bunga BJTM naik } 7,01 \% \\
\text { secara tahunan dari Rp. } 604,37 \\
\text { miliar menjadi Rp. } 647,37 \text { miliar } \\
\text { pada semester I } 2018 \text {. }\end{array}$ & $\begin{array}{l}\text { Harga saham ditutup } \\
\text { melemah dari harga } \\
\text { sebelumnya. }\end{array}$ \\
\hline 10. & 31 Oktober 2018 & $\begin{array}{l}\text { PT. Equity Life Indonesia (Equity Life) menjalin } \\
\text { kemitraan strategis dengan BJTM, yaitu dengan me- } \\
\text { luncurkan dua produk asuransi proteksi multi manfaat } \\
\text { melalui jalur distribusi bancassurance, yaitu Asuransi } \\
\text { Jiwa Proteksi Multi Investa dan Sejahtera. }\end{array}$ & $\begin{array}{l}\text { Dalam berkemitraan dengan } \\
\text { Equity Life, BJTM memperoleh } \\
\text { kontribusi pendapatan premi } \\
\text { dari bancassurance mencapai } \\
15 \% \text {, dan diharapkan kedepanya } \\
\text { dapat tumbuh menjadi } 30 \% \text {. }\end{array}$ & $\begin{array}{l}\text { Harga saham tidak men- } \\
\text { galami perubahan atau } \\
\text { stagnan. }\end{array}$ \\
\hline 11. & 25 Januari 2019 & $\begin{array}{l}\text { Jumlah rasio kecukupan modal atau Capital Adequacy } \\
\text { Ratio (CAR) BJTM turun tipis dari } 24,65 \% \text { ke } 24,21 \% \\
\text { yoy di pengunjung akhir tahun 2017. Aksi korporasi } \\
\text { yang dilakukan untuk mengatasinya adalah dengan } \\
\text { menekan rasio Non-Performing Loan (NPL). Angka NPL } \\
\text { semakin naik mendekati } 5 \% \text { pada awal 2019. }\end{array}$ & $\begin{array}{l}\text { BJTM lebih focus menekan laju } \\
\text { rasio kredit bermasalah atau } \\
\text { NPL dari pada melakukan } \\
\text { ekspansi di tahun } 2018\end{array}$ & $\begin{array}{l}\text { Harga saham ditutup } \\
\text { menguat dari harga sebe- } \\
\text { lumnya. }\end{array}$ \\
\hline 12. & 28 Maret 2019 & $\begin{array}{l}\text { BJTM bekerja sama dengan PT. Asuransi Jiwa Sinarmas } \\
\text { MSIG, meluncurkan tiga produk telemarketing yaitu } \\
\text { SMiLe Medical Care, SMiLe Hospital Cash Plan dan } \\
\text { SMiLe Term ROP }\end{array}$ & $\begin{array}{l}\text { BJTM mengembangkan bisnis } \\
\text { bancassurance dengan Sinarmas } \\
\text { MSIG life. }\end{array}$ & $\begin{array}{l}\text { Harga saham ditutup } \\
\text { menguat dari harga sebe- } \\
\text { lumnya. }\end{array}$ \\
\hline
\end{tabular}

Sumber: RTI Business 
Berdasarkan data atau kebijakan perusahaan yang telah dipaparkan diatas, maka pergerakan harga BJTM tidak berbanding lurus dengan berita atau kebijakan yang beredar, dalam pengertian munculnya berita baik maka harga saham akan naik ataupun sebaliknya. Sebagai contohnya, di tahun 2016, kebijakan perusahaan bekerjasama dengan pihak luar seperti Jamkrindo, namun pada saat itu harga saham ditutup melemah.

Akan tetapi, terdapat berita atau kebijakan positif yang memberikan dampak yang positif terhadap pergerakan harga saham BJTM. Sebagai contohnya pada tanggal 28 Maret 2019, Bank Jatim bekerjasama dengan PT. Asuransi Jiwa Sinarmas, dan pada saat itu harga BJTM ditutup menguat pada hari itu juga. Hal ini mengindikasikan bahwa investor menyetujui hasil keputusan kebijakan yang telah di rancang dan dilaksanakan oleh BJTM.

Jadi secara keseluruhan pergerakan harga saham BJTM tidak berpengaruh secara langsung atau berdampak signifikan oleh suatu kebijakan atau fakta yang dilakanakan atau dialami oleh perusahaan.

Selanjutnya, berdasarkan informasi di Tabel 3, maka berita atau fakta kebijakan perusahaan yang terjadi biasanya mempengaruhi pergerakan harga suatu saham.Namun dalam hal ini, kebijakan tidak terlalu memberi dampak yang selaras dalam pergerakan harga saham BJBR.Hal ini berarti munculnya berita baik suatu perusahaan tidak berbanding lurus dengan harga saham hari itu. Sebagai contohnya, pada tanggal 09 Desember 2016, telah terlaksana peluncuran kartu e-money oleh BJB bekerja sama dengan Bank Mandiri, namun pada saat itu harga saham ditutup melemah.

Jadi berdasarkan tabel 3, maka fakta menunjukkan secara keseluruhan pergerakan harga saham BJBR tidak berpengaruh secara langsung atau berdampak signifikan oleh suatu kebijakan atau fakta yang dilakanakan atau dialami oleh perusahaan. 
TABEL 3.BERITA YANG BERDAMPAK PADA HARGA SAHAM BJBR

\begin{tabular}{|c|c|c|c|c|}
\hline No. & Tanggal & Fakta atau Kebijakan & Dampak terhadap Perusahaan & $\begin{array}{c}\text { Harga Penutupan saham dari } \\
\text { hari } \\
\text { sebelumnya. }\end{array}$ \\
\hline 1. & 29 Februari 2016 & $\begin{array}{l}\text { BJBR membukukan kenaikan laba bersih dari } \\
1,10 \mathrm{~T} \text { menjadi } 1,38 \mathrm{~T} \text {. Kenaikan ini adalah } \\
\text { sebesar } 24,7 \% \text { per Desember } 2015 \text {. Pertum- } \\
\text { buhan laba ini disebabkan karena rasio kredit } \\
\text { bermasalah atau non performing loan (NPL) } \\
\text { mengalami penurunan. }\end{array}$ & $\begin{array}{l}\text { Hasil penurunan angka NPL dikare- } \\
\text { nakan perusahaan BJB sangat selektif } \\
\text { dalam menyalurkan kredit mikro dan } \\
\text { kredit rumah. }\end{array}$ & $\begin{array}{l}\text { Harga saham ditutup menguat } \\
\text { dari harga sebelumnya. }\end{array}$ \\
\hline 2. & 10 Agustus 2016 & $\begin{array}{l}\text { BJB dipilih menjadi penampung dana amnesti } \\
\text { pajak. Hal ini karena BJB sudah termasuk } \\
\text { Bank Umum Kelompok Usaha (BUKU) III, } \\
\text { dimana BJB memiliki jaringan dan layanan } \\
\text { yang menyebar ke seluruh wilayah Indonesia. }\end{array}$ & $\begin{array}{l}\text { BJB ditunjuk resmi sebagai bank daerah } \\
\text { pertama penampung dana repatriasi } \\
\text { program amnesti pajak. }\end{array}$ & $\begin{array}{l}\text { Harga saham ditutup melemah } \\
\text { dari harga sebelumnya. }\end{array}$ \\
\hline 3. & 09 Desember 2016 & $\begin{array}{l}\text { PT. Bank Mandiri Tbk berkolaborasi dengan } \\
\text { bank BJB melakukan co-branding uang el- } \\
\text { ektronik. Kolaborasi ini merupakan salah satu } \\
\text { strategis bisnis perseroan dalam memperluas } \\
\text { pangsa pasar penggunaan kartu prabayar } \\
\text { uang elektronik }\end{array}$ & $\begin{array}{l}\text { Kartu e-money Bank BJB resmi di- } \\
\text { luncurkan oleh Senior EVP Chief Tech- } \\
\text { nology Officer Bank Mandiri , yaitu } \\
\text { Joseph Georgino dan Direktur bank BJB } \\
\text { Ferniyanti di Jakarta. }\end{array}$ & $\begin{array}{l}\text { Harga saham ditutup melemah } \\
\text { dari harga sebelumnya. }\end{array}$ \\
\hline 4. & 29 Maret 2017 & $\begin{array}{l}\text { BJB bagikan deviden sebesar Rp. } 89 \text { per } \\
\text { lembar saham atau setara dengan jumlah total } \\
\text { uang Rp. } 862.9 \text { milliar. } \\
\text { Total deviden ini setara } 55 \% \text { dari laba bersih } \\
\text { tahun } 2016 \text { yaitu sebesar Rp. } 1.56 \text { Triliun. }\end{array}$ & $\begin{array}{l}\text { BJB memperoleh laba bersih naik } \\
\text { sebesar } 14.4 \% \text { yoy di } 2016 \text { dan rasio } \\
\text { NPL membaik pada akhir tahun } 2016 \\
\text { sebesar } 1.69 \% \text { dari } 2.91 \% \text { pada akhir } \\
\text { tahun } 2015 \text {. }\end{array}$ & \\
\hline 5. & 22 Juni 2017 & $\begin{array}{l}\text { BJB menerbitkan surat utang yaitu Negotiable } \\
\text { Certificate of Deposit (NCD) sebesar Rp. } 500 \\
\text { miliar. NCD ini telah terdaftar dalam KSEI, } \\
\text { dimana nilainya kurang dari } 20 \% \text { dari nilai } \\
\text { ekuitas bank. }\end{array}$ & $\begin{array}{l}\text { Hasil dari penerbitan NCD ini akan } \\
\text { digunakan sebagai modal kerja penya- } \\
\text { luran kredit. }\end{array}$ & $\begin{array}{l}\text { Harga saham ditutup menguat } \\
\text { dari harga sebelumnya. }\end{array}$ \\
\hline 6. & 25 Juli 2017 & $\begin{array}{l}\text { Berita bahwa saham BJBR menjadi penghuni } \\
\text { baru daftar saham LQ45. }\end{array}$ & $\begin{array}{l}\text { Saham BJB menjadi lebih likuid dan } \\
\text { banyak diperjualbelikan di lantai bursa. }\end{array}$ & $\begin{array}{l}\text { Harga saham ditutup melemah } \\
\text { dari harga sebelumnya. }\end{array}$ \\
\hline 7. & 27 Oktober 2017 & $\begin{array}{l}\text { BJBR menerbitkan obligasi melalui pena- } \\
\text { waran umum berkelanjutan atau PUB, } \\
\text { dengan target penghimpunan dana sebesar } \\
\text { Rp. 4,5 triliun. Obligasi yang diterbitkan } \\
\text { memperoleh peringkat id AA- (double A } \\
\text { minus) dan id A (Single A). }\end{array}$ & $\begin{array}{l}\text { Bank BJB menunjuk empat perusahaan } \\
\text { penjamin emisi yakni CIMB Sekuritas } \\
\text { Indonesia, BCA Sekuritas, RHB Seku- } \\
\text { ritas Indonesia dan Sucor Sekuritas. }\end{array}$ & $\begin{array}{l}\text { Harga saham ditutup menguat } \\
\text { dari harga sebelumnya. }\end{array}$ \\
\hline 8. & 21 Februari 2018 & $\begin{array}{l}\text { Bank BJB menyuntik dana PT. Asuransi } \\
\text { Bangun Askrida sebesar Rp. 10,14 miliar. }\end{array}$ & $\begin{array}{l}\text { Bank BJB memiliki saham bank di } \\
\text { asuransi ini sebesar } 10,14 \% \text {. }\end{array}$ & $\begin{array}{l}\text { Harga saham tidak mengalami } \\
\text { perubahan atau stagnan. }\end{array}$ \\
\hline 9. & 14 Mei 2018 & $\begin{array}{l}\text { Bank BJB mencatat nilai Net Interest Margin } \\
\text { (NIM) per akhir } 2018 \text { sebesar } 6,1 \% \text {, dimana } \\
\text { nilai tersebut meningkat } 0,1 \% \text { dibandingkan } \\
\text { dengan posisi di akhir Maret } 2018 \text {. }\end{array}$ & $\begin{array}{l}\text { Strategi yang sudah dilakukan oleh BJB } \\
\text { yaitu dengan ekspansi penyaluran } \\
\text { kredit consumer ke pensiunan. }\end{array}$ & $\begin{array}{l}\text { Harga saham tidak mengalami } \\
\text { perubahan atau stagnan. }\end{array}$ \\
\hline 10. & 20 November 2018 & $\begin{array}{l}\text { PT. Bank Pembangunan Daerah Jawa Barat } \\
\text { dan Banten Tbk. (BJBR) akan melepaskan } \\
\text { nama Banten yang akan digelar pada Rapat } \\
\text { Umum Pemegang Saham Luar Biasa atau } \\
\text { RUPLSB pada } 11 \text { Desember } 2018\end{array}$ & $\begin{array}{l}\text { BJB akan melepaskan nama Banten } \\
\text { dalam anggaran dasar dan pergantian } \\
\text { kepengurusan. }\end{array}$ & $\begin{array}{l}\text { Tidak terjadi transaksi pada hari } \\
\text { libur bursa. Namun pada tang- } \\
\text { gak } 21 \text { november 2018, harga } \\
\text { saham perdagangan di bursa } \\
\text { ditutup melemah }\end{array}$ \\
\hline 11. & 20 Januari 2019 & $\begin{array}{l}\text { Saham BJBR keluar dari indeks LQ45 dan } \\
\text { tergantikan oleh saham lain. Indeks LQ45 ini } \\
\text { diukur berdasarkan performa harga, likuidi- } \\
\text { tas tinggi dan kapitalisasi pasar yang besar } \\
\text { yang didukung oleh fundamental yang baik. }\end{array}$ & $\begin{array}{l}\text { Saham BJB menjadi kurang likuid dan } \\
\text { menjadi saham second liner oleh para } \\
\text { investor untuk diburu. }\end{array}$ & $\begin{array}{l}\text { Tidak terjadi transaksi pada hari } \\
\text { libur bursa. Namun pada tang- } \\
\text { gak } 21 \text { Januari 2019, harga saham } \\
\text { tidak mengalami perubahan } \\
\text { atau stagnan. }\end{array}$ \\
\hline 12. & 24 Mei 2019 & $\begin{array}{l}\text { Penandatanganan MOU tentang fasilitas } \\
\text { kredit modal antara PT. Kharisma Pemasaran } \\
\text { Bersama Nusantara (KPBN) dengan Lembaga } \\
\text { Pembiayaan Ekspor Indonesia (LPEI) dan } \\
\text { bank BJB sebesar Rp. } 400 \text { miliar. }\end{array}$ & $\begin{array}{l}\text { Perusahaan BJB memberikan dukungan } \\
\text { dan pinjaman kredit kepada KPBN. }\end{array}$ & $\begin{array}{l}\text { Harga saham ditutup menguat } \\
\text { dari harga sebelumnya. }\end{array}$ \\
\hline
\end{tabular}

Sumber: RTI Business 


\section{SIMPULAN}

Bila ditinjau dari sisi analisa fundamental masing-masing perusahaan, dapat dikatakan bahwa saham BJBR memberikan data-data pertumbuhan rasio pengembalian aset dan ekuitas yang lebih baik dibandingkan dengan BJTM.Akan tetapi, pertimbangan dalam hal nilai persentase pembagian nilai deviden BJTM memiliki persentase yang lebih besar daripada BJBR.Nilai deviden per lembar saham nya memiliki persentase hampir $8-9 \%$ setiap tahunnya.Sedangkan untuk besar deviden per lembar sahamnya memilki persentase sebesar 4-6\% setiap tahunnya. Harga saham yang beredar di pasar akan memberikan pengaruh secara psikologis bagi para investor untuk memilih antara BJBR dan BJTM. Harga saham BJTM di pasar jauh lebih murah yang berkisar diantara 600-700 per lembar saham sedangkan BJBR diharga 1800-2300 per lembar saham.

Bila ditinjau dari sisi analisa teknikal, kedua saham menunjukkan tren yang hampir sama. Siklus penurunan harga terjadi setelah pembagian dividen yaitu bulan Mei sampai bulan september. Penurunan harga saham cukup signifikan sekitar 10\% untuk BJBR dan BJTM.Siklus kenaikan kedua saham ini berada dibulan oktober - Maret.

Bila ditinjau dari sisi fakta atau kebijakan yang dilaksanakan oleh perusahaan BJTM dan BJB, dapat dikatakan bahwa fakta tidak memberikan dampak yang signifikan terhadap perubahan harga saham.Fakta atau kebijakan positif yang di rilis ke media tidak mampu mendongkrak harga saham BJB dan BJTM. Namun justru sebaliknya, fakta positif akan berdampak negatif bagi pergerakan harga saham.

Jadi secara keseluruhan BJBR dan BJTM sangat layak untuk di investasikan, mengingat kedua bank pemerintah daerah ini sudah mampu menunjukkan kinerja yang lebih baik setiap tahunnya.Hal ini dibuktikan dengan penurunan angka NPL dan kenaikan jumlah pemberian kredit kepada peminjam. Akan tetapi, saham BJBR lebih layak di investasikan untuk jangka panjang apa bila dibandingkan dengan BJTM.

Bagi penelitian selanjutnya, peneliti dapat menganalisis lebih dalam dan lebih banyak lagi tentang rasio-rasio keuangan perusahaan.Selain itu pengukuran pergerakan harga saham secara teknikal, juga menggunakan metode yang lebih beragam.

\section{REFERENCES}

Animah, Sasanti, E. E., dan Karina, N. (2009). Pengaruh Profit Margin, Investment Turn- over, Equity Multiplier Terhadap Return on Equity. Jurnal Telaah \& Riset Akuntansi, 2(2), 165-182.

Dropsy, V. (1996). Do Macroeconomic Factors Help in Predicting International Equity Risk Premia?: Testing The Out-Of-Sample Accuracy of Linear and Non Linear Forecasts. Journal of Applied Business Research, 12(3), 120-132.

Erica, D. (2017). Analisa Rasio Laporan Keuangan Untuk Menilai Kinerja Perusahaan PT SEMEN INDONESIA TBK (PERSERO). Perspektif: Jurnal Ekonomi dan Manajemen UniversitasBina Sarana Informatika, 15(2), 89-94.

Fabozzi, F. J. (2009). Institutional Investment Management: Equity and Bond Portfolio Strategies and Application. New Jersey: Joh Wiley \& Sons, Inc.

Hery. (2017). Analisis Laporan Keuangan. Jakarta: Grasindo.

Kang, H. dan Petzke, S. (2009). Study Guide To Accompany 'Accounting: Building Business Skills' (3 ${ }^{\text {rd }}$ Edition). Australia: John Wiley \& Sons.

Kaplan, R., dan Norton, D., (1992), The Balanced Scorecard - Measures that Drive Performance. Harvard Business Review, January-February 1992.

Komariah, A. dan Satori, D. (2011).Metode Penelitian Kualitatif. Bandung: Alfabeta.

Mudawamah, S., Wijono, T. dan Hidayat, R. R. (2018). Analisis Rasio Laporan Keuangan Untuk Menilai Kinerja Keuangan Perusahaan (Studi pada Bank Usaha Milik Negara yang Terdaftar di Bursa Efek Indonesia Tahun 2013-2015). Jurnal Administrasi Bisnis, 54(1), 20-29.

Mulia, F. M. dan Nurdhiana. (2012). Pengaruh Book Value (BV), Price to Book Value (PBV), Earning Per Share (EPS), dan Price Earning Ratio (PER) Terhadap Harga Saham Perusahaan Food and Beverage yang Terdaftar di Bursa Efek Indonesia Tahun 2007 - 2010. Jurnal Kajian Akuntansi dan Bisnis, 1( 1), 1-19.

Munawir. (2010). Analisa Laporan Keuangan (Edisi Ke-4). Yogyakarta: Liberty.

Ong, E. (2008). Technical Analysis for Mega Profit. Jakarta: Mega Options.

Sukmadinata, N. S. (2011). Metode Penelitian Pendidikan. Bandung: Remaja Rosadakarya.

Tryfino. (2009). Cara Cerdas Berinvestasi Saham. Jakarta: Transmedia Pustaka. 